\title{
Relationship between efficacy of mating disruption and gypsy moth density
}

\author{
Ksenia S. Onufrieva ${ }^{a}$, Andrea D. Hickman ${ }^{a}$, Donna S. Leonard ${ }^{b}$ and Patrick C. Tobin ${ }^{c}$ \\ ${ }^{a}$ Department of Entomology, Virginia Tech, Blacksburg, VA, USA; ${ }^{b}$ USDA Forest Service, Forest Health Protection, Asheville, NC, USA; ' ${ }^{\mathrm{C}} \mathrm{S}$ 'hool \\ of Environmental and Forest Sciences, University of Washington, Seattle, WA, USA
}

\section{ABSTRACT}

Mating disruption tactics involve the deployment of pheromones to interfere with mate finding behaviors in insect populations. This management strategy is the dominant one used against expanding gypsy moth populations in the United States, and historically it has been assumed to be most effective against low-density populations. Operationally, mating disruption is used in areas where the season-long trap catch is $<30$ males/trap, however the maximum population density at which mating disruption is effective remains unknown. We analysed historical gypsy moth mating disruption treatment data from 2000 to 2010, and used this information to guide the mating disruption field studies conducted from 2012 to 2015 against artificially-created populations of various densities, from 0 to 116 males/trap/day. We observed that mating disruption tactics at a dose of $15 \mathrm{~g} \mathrm{Al} / \mathrm{ha}$ were effective against gypsy moth populations with a season-long trap catch of at least 115 males/trap. This research highlights the utility of mating disruption in higher gypsy moth densities than what is currently recommended in management programs.
ARTICLE HISTORY

Received 18 December 2017 Accepted 12 March 2018

\section{KEYWORDS}

Lymantria dispar; mating disruption; pheromone; disparlure; population density

\section{Introduction}

The implementation of control strategies against insect pests requires a number of considerations including cost, resistance management, potential effects to nontarget species, and compatibility with other tactics within an integrated pest management program (Pimentel 1995; Witzgall et al. 2010; Biondi et al. 2012; Suckling et al. 2012; Onstad 2014). One control strategy that has many benefits with regard to these considerations is mating disruption. Mating disruption involves the deployment of synthetic sex pheromones at levels that interfere with mate-finding ability through competitive attraction to the dispensers, habituation of receptors, camouflage of the plumes from calling females, overstimulation, or sensory imbalance (Granett and Doane 1975; Richerson et al. 1976; Carde and Minks 1995; Miller et al. 2006a, 2006b). As such, non-target effects are thought to be rare given that even the target organism is not killed. Moreover, mating disruption is also compatible with other pest management strategies including biological control (Suckling et al. 2012), and can decrease the risk of resistance by reducing mating among resistant individuals (Hide and Suckling 1988; Suckling et al. 1990; Caprio and Suckling 1995).

At present, mating disruption is used against a number of insect pest species, and mostly, but not exclusively, against Lepidoptera (Rice and Kirsch 1990; Bengtsson et al. 1994; Carde and Minks 1995; Witzgall et al. 1999; Thorpe et al. 2006; Walton et al. 2006; Stelinski et al. 2013; Miller and Gut 2015). Although the precise mechanism of mating disruption is not fully understood and may differ among species, a prior theoretical study (Miller et al. 2006a) suggested that mating disruption could work through competitive attraction (false-plume-following), which furthermore suggests that its efficacy could be density-dependent. In support of this, field studies have shown that in some species, such as codling moth (Cydia pomonella), European grape berry moth (Eupoecilia ambiguella), and European grapevine moth (Lobesia botrana), applications of mating disruption are successful only at low pest population densities(Louis and Schirra 2001; Witzgall et al. 2008). Yet, in some species, such as the oriental fruit moth (Grapholita molesta) and tomato pinworm (Keiferia lycopersicella), mating disruption treatments are less sensitive to population density as treatments are effective even when population densities are relatively high (Baker and Cardé 1979; Jenkins et al. 1990). Thus, competitive attraction is likely not the only mechanism by which mating disruption could affect mate finding behavior (Miller et al. 2006a). In this study, we show that mating disruption against the gypsy moth (Lymantria dispar), an invasive non-native insect species in North America, can be effective at higher, population densities than previously thought.

The gypsy moth is managed in the United States through one of three programs: suppression of 
outbreaks in the infested area, eradication of isolated populations in areas that are not yet infested, and through the Slow-the-Spread (STS) program along the expanding population front (Tobin et al. 2012). In the STS program, mating disruption is the dominant control tactic due to its low cost (approximately 18.68 $\$ U S D / h a)$ and absence of adverse effects to non-target organisms(Thorpe et al. 2006). Its use varies each year but generally $>125,000$ hectares are treated annually using mating disruption, http://na.fs.fed.us/fhp/gm/. The basis of mating disruption against of the gypsy moth is rooted in earlier work (Beroza and Knipling 1972; Beroza et al. 1974; Knipling 1979) that initially showed its effectiveness but generally only against sparse populations; however, other studies havedemonstrated successful mating disruption in plots with higher moth densities (Granett and Doane 1975; Schwalbe and Mastro 1988).

Based upon this prior research and the understanding of its efficacy, under current operational standards in the STS program mating disruption is generally used against populations in which the maximum male moth density does not exceed 30/trap/season (Thorpe et al. 2006). For populations above this threshold, the biopesticide Bacillus thuringensis var. kurstaki (Btk) is generally used (Tobin et al. 2007). However, in cases of financial constraints (the cost for Btk per hectare is $\sim 3$ times greater than the cost for mating disruption) or in cases of non-target concerns (Btk can affect nontarget Lepidoptera), the STS program has used mating disruption against high population densities without fully understanding its effectiveness at these higher densities. Furthermore, there are no studies to date that have specifically been designed to quantify the threshold above which mating disruption treatment is no longer effective. In this study, we analyzed historical data from the STS program (2000-2010) on the use of mating disruption across a range of moth population densities and habitats, and coupled this analysis with a 4-year experimental field study (2012-2015) using artificially-created high gypsy moth densities, to quantify the maximumgypsy moth population density that can be successfully managed using mating disruption.

\section{Materials and methods}

\section{Historical data analysis}

To help guide our experimental field studies, as well as gain insight into the densities at which mating disruption would be expected to be effective, we analyzed historical mating disruption treatment data from the STS program from 2000-2010. During this time, $15,667 \mathrm{~km}^{2}$ were treated using mating disruption tactics in Illinois (53 treatment blocks), Indiana (104 blocks), Minnesota (16 blocks), North Carolina (22 blocks), Ohio (102 blocks), Virginia (155 blocks),
Wisconsin (235 blocks), and West Virginia (20 blocks). Treatment blocks (707 total blocks) ranged in size from 0.05 to $456 \mathrm{~km}^{2}$ (median $=6.4 \mathrm{~km}^{2}$ ).

In each treatment block, we extracted the mean male gypsy moth population density based upon the number of traps that were deployed within the boundary of the block. Gypsy moth is univoltine, and traps are deployed to estimate the season-long trap catch. Gypsy moth densities in treatment blocks ranged from 1 to 59 moths per year (median $=3$ moths per block). We also used trapping data to extract the highest male moth count for any individual trap in each block, which ranged from 1 to 951 (median $=11$ ). We also considered additional variables in our analysis. These included the dose of pheromone used in the block (15, 37.5, or $75 \mathrm{~g} \mathrm{AI} / \mathrm{ha}$ ), and the distance of the block from the area considered to be generally infested with gypsy moth; this generally infested area was defined as an area at which the expected male moth count was 10 moths per trapping area per season (Sharov et al. 1997, Tobin et al. 2007). The Euclidean distancebetween treatment blocks and the generally infested area ranged from 0 to $284.2 \mathrm{~km}$. We also considered the mean basal area of gypsy moth preferred host species in each block. Preferred host species were defined by Liebhold et al. (1995), and basal area was spatially interpolated over the United States using U.S. Forest Service Forest Inventory Analysis data by Morin (2005). Preferred host species include, for example, those within the genera Betula (birch), Crataegus (hawthorn), Populus (aspen), Quercus (oak), Salix (willow), and Tilia (basswood) (Liebhold et al. 1995). Basal area of preferred host species within blocks ranged from 0 to $12.5 \mathrm{~m}^{2} /$ ha. Because basal area estimates were calculated on a grid divided into $1 \times 1 \mathrm{~km}$ cells (Morin 2005), we also estimated the standard deviation (SD) of the basal area per treatment block, from which we estimated the coefficient of variation $(\mathrm{CV}=\mathrm{SD} /$ mean $\times 100$ ) of the basal area per block. The values of CV ranged from 0 to 151 , and allowed us to also consider the variability in the density of gypsy moth preferred host species in each block. Lastly, we extracted the mean elevation (meters above sea level) in each block based upon 30-m USGS National Elevation Data (Gesch et al. 2002). The mean elevation in blocks ranged from 0 to $1,204.6 \mathrm{~m}$. We also estimated the SD of elevation, from which we estimated the $\mathrm{CV}$ in each block; values of CV ranged from 0 to 38.4. We considered the mean elevation and the $\mathrm{CV}$ of elevation due to prior work that demonstrated that topography can affect gypsy moth developmental synchrony and matefinding behavior (Walter et al. 2015), which could also affect the effectiveness of a tactic that aims to disrupt mate-finding.

We considered a suite of predictor variables (treatment block area, mean moth density, maximum moth catch, mating disruption dose, distance from infested 
area, mean and CV of the basal area of host plants, and mean and CV of elevation) on the effectiveness of mating disruption treatments. The effectiveness of mating disruption treatments was based upon an index of treatment success, $T$, developed in prior work (Sharov et al. 2002; Thorpe et al. 2007). Briefly, $T$ is calculated according to:

$$
T=\left(\frac{N_{2}}{N_{1}} \times \frac{C_{1}}{C_{2}}\right)
$$

in which $N_{i}$ is the mean moth density in the treatment block in the year before $(i=1)$ or after $(i=2)$ treatment, and $C_{i}$ is the mean moth density in an area outside of the treatment block (which serves as spatially untreated control block) in the year before $(i=1)$ or after $(i=2)$ treatment. A treatment with a value of $T>0.66$ is considered to be successful; additional details about $T$ can be found in (Sharov et al. 2002) and (Tobin et al. 2007). We considered $T$ in each treatment block as a binary response variable (i.e., a failed or successful treatment) and assessed the significance of predictor variables using logistic regression. We considered all main effects, biologically meaningful interaction effects (i.e., moth catch-by-treatment area, moth catch-by-basal area), and when appropriate, squared terms of main effects (i.e., in the case of nonlinear relationships between a main effect and the response variable). Statistical analyses were conducted in R (R Development Core Team 2016).

\section{Experimental field studies}

We conducted field studies in the Goshen Wildlife Management Area (GWMA) and George Washington and Jefferson National Forest (GWJNF), VA, USA, from 2012-2015 (Supplemental Material 1). In each year, we used a similar experimental design but altered certain aspects, depending on our findings from the previous year, in an effort to quantify the male moth density at which mating disruption failed. In each year, we used two experimental blocks with two $500 \times 1000 \mathrm{~m}$ plots separated by at least $1 \mathrm{~km}$ in each block. In each block, one plot was left untreated and used as control, and one plot was treated with Hercon Disrupt $^{\oplus}$ II at $15 \mathrm{~g} \mathrm{AI} / \mathrm{ha}$, which is the most common dosage used operationally in the STS program.Mating success was evaluated using laboratory-reared gypsy mothsobtained as pupae from the USDA Animal and Plant Health Inspection Service, Pest Survey Detection and Exclusion Laboratory, OTIS Air National Guard Base, Buzzards Bay, MA, USA. Pupae were kept in laminated paper cups with plastic lids. A fluorescent dye solvent red 26 (Royce International, Paterson, NJ) was added to the larval diet at the rearing facility, which was expressed in adults and was used to differentiate between released and background male moths.
In all experiments, naturally flightless,virgin European gypsy moth females were left on tree boles for $24 \mathrm{~h}$ and protected from predation by a band of Tanglefoot ${ }^{\circledast}$ bird repellent (Thorpe et al. 2007). After $24 \mathrm{~h}$, females were collected andkept in the laboratory to deposit egg masses. Egg masses were kept for at least 60 days to allow for embryonation, after which they were inspected to determine their fertilization status (Stark et al. 1974; Sharov et al. 1995; Tcheslavskaia et al. 2002). Male moth recapture was measured usingstandard USDA milk-carton pheromone traps baited with $500 \mu \mathrm{g}$ of $(+)$-disparlure in twine dispensers (Scentry Biologicals, Inc, Billings, MT, USA).

\section{Preliminary field study}

We conducted a preliminary study in 2012 to quantify our ability to simulate low- and high-density gypsy moth populations, and to measure the effect of mating disruption treatments on gypsy moth mating success at different densities. In this preliminary study, and for each deployment, we used one block of two plots (one treated and one untreated control) to simulate lowdensity populations, while the remaining block of two plots (one treated and one untreated control) was used to simulate high-density populations.We alternated the blocks used to simulate high- and low-density populations on a weekly basis to reduce bias, therefore each treatment/density combination was replicated twice. Low-density populations were achieved by releasing 100 males in each of the 3 release points and deployment of 15 females in a $50-\mathrm{m}$ radius circle around the central male moth release point (Supplemental Material 2). High-density was achieved by releasing 500 males at each of the 3 release points and deployment of 75 females in a 50-m radius circle. We deployed females 4 days a week and released males twice a week, over 9 weeks. Pheromone-baited traps were checked and emptied at the time of male moth release to estimate population densities in experimental plots and evaluate the efficacy of mating disruption treatments. The proportion of fertilized females on each day was transformed using an arcsine-square root transformation. We tested the main effect of treatment (mating disruption treatment or untreated control), male moth density, and their interaction using analysis of variance (ANOVA) in SAS (2008).

The trap catches in untreated control plots ranged from 2.62 to 8.5 males/trap/day. Pheromone treatment reduced male moth catches in pheromone-baited traps by over $90 \%$ compared to untreated control plots, regardless of the population density (Figure 1A). Mating success of females in treated plots were reduced by $\geq 95 \%$ compared to control plots (Figure 1B). These results indicate that pheromone treatments reduce male moth catches in pheromone-baited traps in the same manner regardless of the population density, 


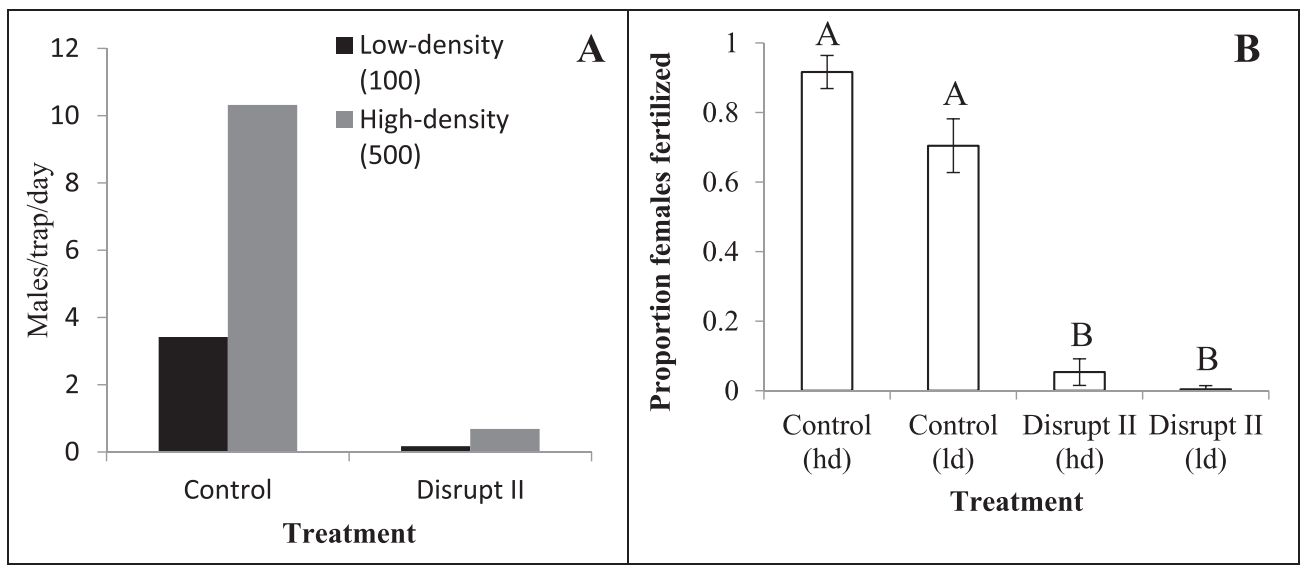

Figure 1. Average daily male moth catches in USDA milk carton pheromone-baited traps (A) and mating success of females (B) at various densities of gypsy moths in VA, 2012.

while at higher population densities mating success of females in untreated plots approaches 100\%. These results justified our decision to use different experimental designs for control and treated plots in 20132015. The numbers of males we planned to release in 2013-2015 was more than enough to ensure that very close to $100 \%$ of the females would be mated in the untreated control plots; thus $100 \%$ mating of females could be assumed without deploying any femalesin the control plots. Conversely there was no need to deploy pheromone baited traps in the treated plots where females were deployed because it could be assumed that trap catch would be suppressed by at least $90 \%$ by the treatment.

Segregating male recapture in pheromone-baited traps to our control plots and female mating success to our treated plots allowed us to avoid competition between females and pheromone-baited traps without losing any information. In the STS program, a decision to treat an area is based on the trap catches in the year prior to the treatment, while mating success of females needs to be assessed during the year of treatment, therefore this experimental design was an appropriate simulation of operational STS program.

\section{Subsequent field studies}

Due to the limited number of males that we could get from the rearing facility, we had to reduce the number of male moth release points to be able to simulate a wider range of population densities. Therefore, in 2013-2015 in each of the two control plots, we established a single male moth release point surrounded by four pheromone-baited traps (Supplemental Material $3 \mathrm{~A}$ ). In each of the treated plots, we established 5, 25 and $50 \mathrm{~m}$ radiiconcentric circles of treesaround a male moth release point for female deployment (Supplemental Material 3B). In 2013, only the outer $50 \mathrm{~m}$ radius circle was used; in 2014, all three circles were used; and in 2015, 5 and $25 \mathrm{~m}$ radii circles were used.
We deployed 100 females 4 times/week, and at the time of female deployment, we released the same number of males on both the control and treatment plots and checked and emptied all pheromone-baited traps in treated plots. Number of released males ranged $80-$ 1100 per release in $2013,150-1700$ per release in 2014 and $100-715$ per release in 2015.

\section{Statistical analysis}

We used logistic regression (PROC GENMOD, SAS Institute 2008) to analyze mating success of females in treated plots at various densities and distances from the male moth release point. Deployed females were scored as either mated or not, and this binary variable was adjusted by the number of females returned (as despite our efforts, some females still succumbed to predation) and modeled as a function of male moth density.Significance was based on the likelihood ratio chi-squared, $G^{2}$, and when appropriate, we estimated odds ratios and associated confidence intervals.

\section{Results}

\section{Historical data analysis}

We observed that treatment success was significantly positively affected by the area of the treatment block $\left(\mathrm{G}^{2}=7.5, P<0.01\right)$ and the maximum moth catch in the block $\left(\mathrm{G}^{2}=5.1, P<0.01\right)$, while treatment success was significantly negatively affected by the $\mathrm{CV}$ of elevation $\left(\mathrm{G}^{2}=3.9, P=0.04\right)$ and the maximum moth catch squared $\left(G^{2}=6.7, P<0.01\right)$. No other main or interacting terms were significant. It is noteworthy that while the maximum moth catch did affect treatment success, mean moth catch did not $\left(\mathrm{G}^{2}=0.3, P=0.62\right)$. These results suggested that smaller blocks had a greater tendency for treatment failure, perhaps due to difficulties in ensuring adequate pheromone coverage in smaller treatment blocks. Moreover, an increase in 
the hilliness of blocks, as proxied by the CV of elevation, increased the probability of treatment failure, perhaps due to potential gypsy moth reproductive asynchrony in hillier terrain (Walter et al. 2015). Most interesting was the relationship between the maximum moth count and its squared term on treatment success, which suggests a potential optimal range of maximum moth catch relative to mating disruption (Figure 2). These findings motivated our field experiments.

\section{Experimental field studies}

In 2013, trap catches in untreated control plots ranged from 0 to 59.75 males/trap/day. Odds ratio analysis indicated that likelihood of females getting mated in treated plots is similar when trap catches are $\leq 40 \mathrm{males} / \mathrm{trap} / \mathrm{day}$ and increases at trap catches $>40 \mathrm{males} / \mathrm{trap} / \mathrm{day}$ in corresponding untreated control plots (Table 1).

In 2014, trap catches ranged from 4.5 to 116.75 males/trap/day. We detected significant differences in mating success of females located in treated plots at various distances from the male moth release point $\left(\mathrm{G}^{2}=28.5\right.$; $\mathrm{df}=47 ; P<0.0001$; Figure 3$)$. The likelihood of getting mated was 3 times higher for females located $0-10 \mathrm{~m}$ away from the male moth release point compared to females located 20 and $50 \mathrm{~m}$ away from the release point $(95 \% \mathrm{CI}=1.4,5)$. Overall mating success in treated plots was reduced to $\leq 5 \%$ at trap catches $\leq 20 \mathrm{males} / \mathrm{trap} /$ day in corresponding untreated control plots (Figure 4A). In 2015, trap catches ranged from 2.5-66 males/trap/day. Mating success was reduced by the pheromone treatment in a

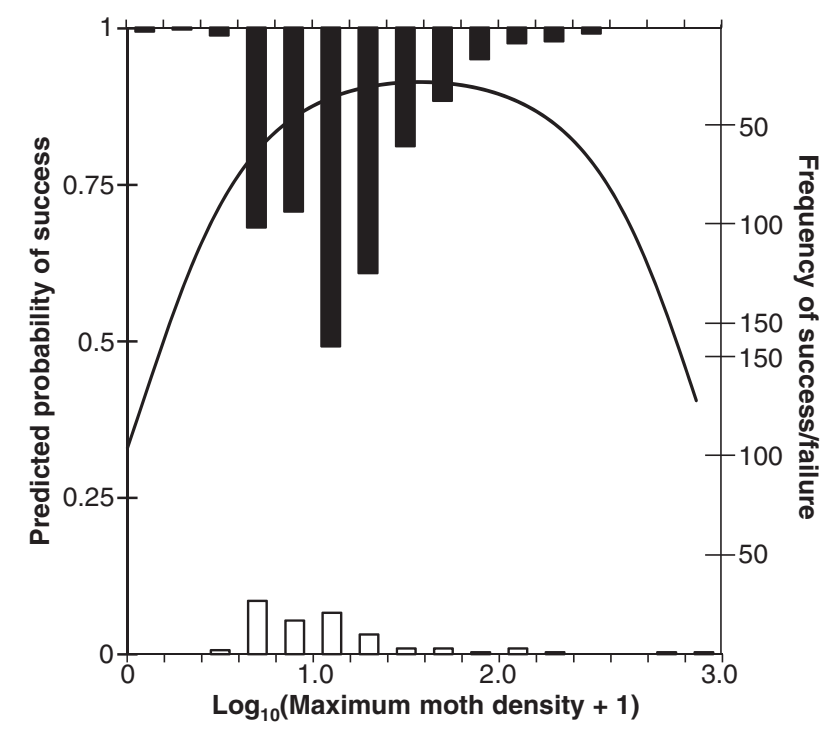

Figure 2. Relationship between treatment success and maximum moth density. The open and closed bars represent the frequency of failures and successes, respectively. The line is the predicted probability of success, indicating the highest probability of success at approximately 30 moths (back-transformed). However, treatment successes were noted at maximum densities as high as 392 moths.
Table 1. Likelihood of females getting mated at various population densities in VA, 2013.

\begin{tabular}{cccc}
\hline $\begin{array}{l}\text { Trap catches, } \\
\text { males/trap/day }\end{array}$ & & Odds ratio & $\mathrm{Cl}$ \\
\hline $0-10$ & $10-30$ & 1 & $0.12-7.3$ \\
$0-10$ & $30-40$ & 1.5 & $0.08-5.7$ \\
$0-10$ & $>40$ & 4 & $0.03-1.8$ \\
$10-30$ & $30-40$ & 1.4 & $0.2-3.2$ \\
$10-30$ & $>40$ & 4 & $0.07-0.97$ \\
$30-40$ & $>40$ & 3 & $0.09-1.4$ \\
\hline
\end{tabular}

similar manner as in 2014 (Figure 4B). The analysis of combined data collected in 2014 and 2015 in the inner circles only confirmed that females are 8 times less likely to get mated in populations characterized by trap catches below 20 males/trap/day compared to higher density populations $(95 \% \mathrm{CI}=0.02,0.6)$. The analysis of all mating success data collected in 20132015 also indicated that overall mating success in treated plots was significantly lower at trap catches below 40 males/trap/day in corresponding untreated control plots $\left(\mathrm{G}^{2}=32.4 ; \mathrm{df}=51 ; P<0.0001\right.$; Figure 5).

\section{Extension to management programs}

In our field studies, we evaluated mating success of gypsy moth females at various population densities of males when measured per trap and per day. We observed that mating success of females from treated plots was at its lowest at male moth densities up to 40 males/trap/day. However, in gypsy moth management programs, the trap catch data on which management decisions are developed are based on season-long trap catch. A prior study related daily trap catch with season-long trap catch according to:

$$
0.96 M_{p d} F<\Sigma<2.87 M_{p d} F
$$

where $\mathrm{M}_{\mathrm{pd}}$ is maximum daily trap catch, $\mathrm{F}$ is flight in weeks, and $\Sigma$ is season-long trap catch(Onufrieva and Onufriev 2018). Given that the duration of male moth flight generally occurs over 6 weeks (Tobin et al. 2009), we estimated season-long trap catch when assuming a range of daily trap catch densities up to 40 males/day/ trap (Table 2).

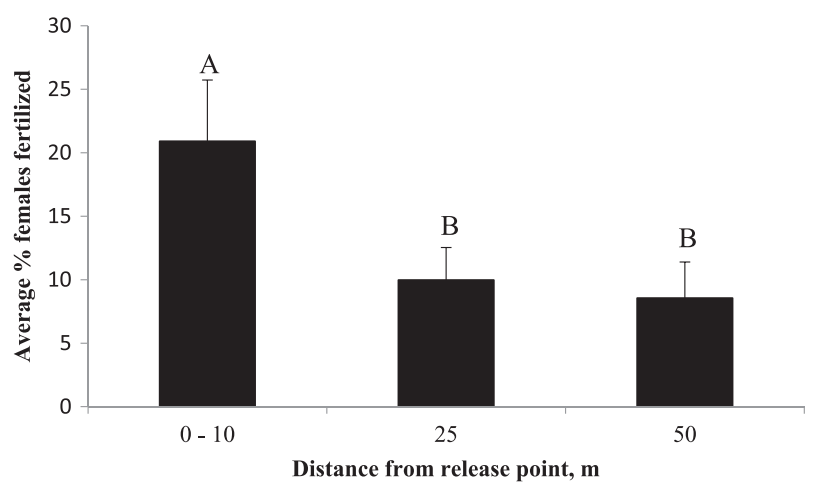

Figure 3. Mating success of gypsy moth females at various distances from a male moth release point, VA 2014. Bars with the same letter are not significantly different. 


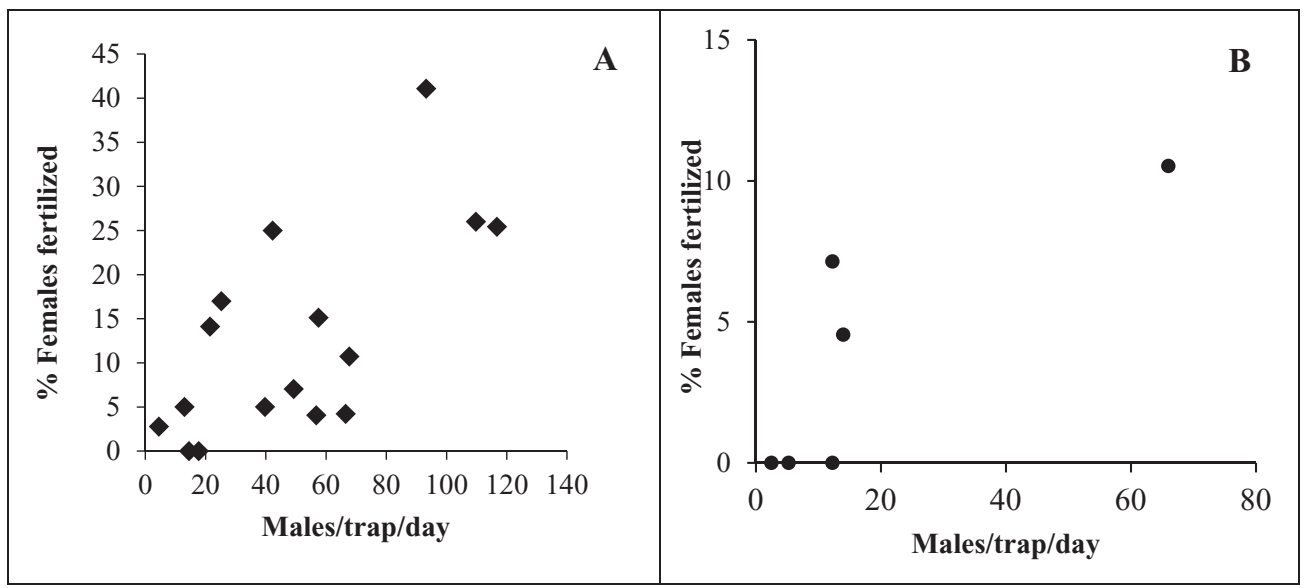

Figure 4. Mating success of gypsy moth females at various male moth catches in USDA milk carton pheromone-baited traps in Virginia, in 2014 (A) and 2015 (B).

\section{Discussion}

In the STS program, a treatment is considered effective if the mating success of females is reduced by at least 95\% compared to control plots (Thorpe et al. 2006). Moreover, to account for the uncertainty associated with trap catch data and the possibility that males and females could be in close proximity and thus potentially less affected by mating disruption treatments, the STS program has assumed 20 males/trap/day to be an upper limit above which mating disruption fails. At this density, the season-long trap catch would range from 115 to 344 males/trap (Table 2). Prior studies suggested that in areas untreated with pheromone the absolute minimum season-long male trap catch that resulted in $99 \%$ female mating was 51.2 males/trap (Tobin, Onufrieva et al. 2013), and at season-long catches $>65$ males/trap, mating success of females approaches $100 \%$ (Thorpe et al. 2006). Therefore, $5 \%$ mating success at trap catches of $\sim 20$ males/trap/day (115 males/trap/season) would indicate a successful mating disruption treatment.

An additional consideration is the use of trap catch data in gypsy moth management decisions. Prior to implementing a treatment, areas are often delineated in the prior year through the use of an intensive

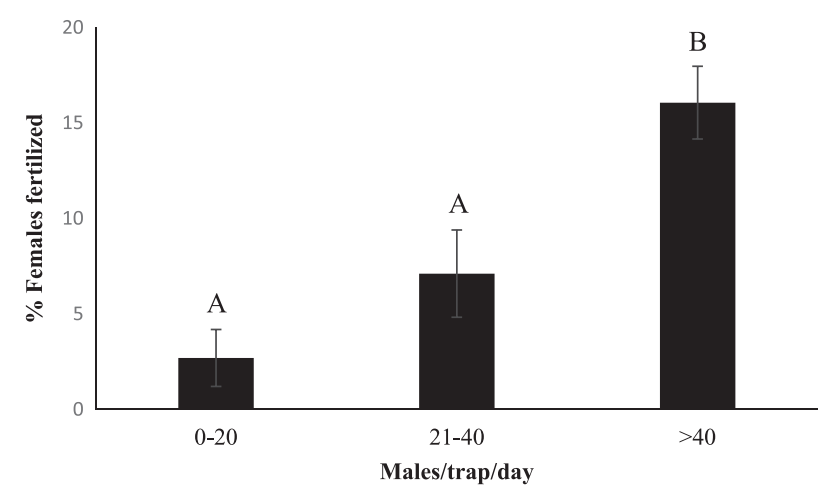

Figure 5. Mating success of females at various male moth catches in USDA milk carton pheromone-baited traps, Virginia, 2013-2015. Bars with the same letter are not significantly different. trapping grid (Sharov et al. 2002, Tobin et al. 2004, Tobin et al. 2012). This is feasible because gypsy moth is univoltine; thus, season-long trap catch can be used to define the area that requires treatment and to prioritize treatments in the following year. However, even in intensive trapping grids, there are gaps between traps that could miss a pocket of denser populations, which would cause the season-long trap catch to be an underestimate of the population density (Tobin, Blackburn et al. 2013). In addition to this challenge, the expected rate of population change from year of monitoring to the year of treatment also needs to be considered. Sharov and Liebhold (1998) reported that for gypsy moth to achieve spread rates in the absence of management programs, which was estimated as $20.78 \mathrm{~km} /$ year (Liebhold et al. 1992), populations would have to increase their numbers by a factor of 5.51 times/year. When assuming this rate of population change, the maximum season-long trap catch at which mating disruption would expected to be successful is estimated as $62 \mathrm{males} /$ trap/season, which is more than double the current operational standard of 30 males/trap/season.

We note that these estimates are based upon work primarily conducted along the southern front of the gypsy moth expanding range. Past work has highlighted the differences in the availability of preferred host tree species (Morin 2005) and rates of spread (Tobin et al. 2007) along the current gypsy moth expanding front, which extends from Minnesota to North Carolina, in addition to the differences in climate. Thus, future work should address the stability of these findings in geographically-different areas.

Table 2. Gypsy moth male season-long abundance predicted from maximum daily catches in pheromone-baited traps.

\begin{tabular}{lc}
\hline $\begin{array}{l}\text { Observed maximum daily } \\
\text { trap catch }\left(\mathrm{M}_{\mathrm{pd}}\right)\end{array}$ & $\begin{array}{c}\text { Predicted range of abundance }(\mathrm{A}) 0.96 \\
\mathrm{M}_{\mathrm{pd}} \mathrm{F}<\mathrm{A}<2.87 \mathrm{M}_{\mathrm{pd}} \mathrm{F}\end{array}$ \\
\hline 10 males/trap/day & $57-172.2$ \\
20 males/trap/day & $115-344$ \\
30 males/trap/day & $172-516$ \\
40 males/trap/day & $230-689$ \\
\hline
\end{tabular}


The utility of mating disruption against highdensity gypsy moth populations was suggested by previous authors (Plimmer et al. 1982; Schwalbe and Mastro 1988). However, many other studies showed mating disruption to be most suitable for suppression and eradication of low-density gypsy moth populations (Beroza and Knipling 1972; Beroza et al. 1974; Knipling 1979), especially isolated and semi-isolated low-density populations along the leading edge of an expanding front (Sharov et al. 2002). Also, in highdensity populations, mate finding may be less likely affected by application of synthetic pheromones due to the decreased distance between males and females. Consequently, mating disruption against high-density populationswas not often used.

Advances in pheromone synthesis, better release profiles achieved by the products, and in the deployment of pheromones in mating disruption applications (Thorpe et al. 2006) have likely increased the efficiency of this tactic against gypsy moth populations. Recent studies have also revealed that pheromone treatments not only significantly reducedthe chance of finding a mate but also increase searching time. This can delay mating and contribute to decreases in fecundity (Mori and Evenden 2013; Tobin et al. 2014) and egg fertilization (Tobin et al. 2014). Although more research is needed to identify the contribution of different factors in the increased efficiency of mating disruption against gypsy moth populations, the results of this study indicate that this tactic can be used against higher densities of gypsy moths than previously thought. Overall, this could potentially reduce the use of other, less benign and economical methods of gypsy moth control.

\section{Acknowledgements}

We thank Hannah Nadel, Christine McCallum, and Susan Lane (USDA APHIS PPQ) for supplying gypsy moth pupae; Mikeal Jolly (Goshen Scout Reservation) for providing facilities and tremendous support; Dave Plunkett, Steve Croy, Wes Nettleton, and Noel Schneeberger (USDA, Forest Service) for administrative support; Mannin Dodd (Virginia Tech) and Laura Blackburn (USDA Forest Service) for technical assistance; Amy Onken (USDA Forest Service) for assistance with aerial applications; Al's Aerial Spraying (Ovid, MI) for providing the aerial applications; Priscilla Maclean (Hercon Environmental, Emigsville, PA) for product support; Ron Hughes, Gene Sours, Bill Mohler, Kent Burtner (VA Department of Game and Inland Fisheries) for providing forest access; Hunter Clark, Lisa Connors and Ben Garber for lab assistance; Department of Entomology at Virginia Tech for providing facilities and equipment. This work was supported by the USDA Forest Service, Forest Health Protection (Grant number 10-CA-11420004-024 to K.S.O.); Rutgers University (Grant number 2012-VA-BDP-Onufrieva to K.S.O.); and the Gypsy Moth Slow-the-Spread Foundation, Inc. (Grant number A97911 to P.C.T.). Mention of a proprietary product does not constitute an endorsement or a recommendation for its use by USDA.

\section{Disclosure statement}

No potential conflict of interest was reported by the authors.

\section{Funding}

This work was supported by the USDA Forest Service, Forest Health Protection [grant number 10-CA-11420004-024 to K.S.O.]; Rutgers University [grant number 2012-VA-BDPOnufrieva to K.S.O.]; and the Gypsy Moth Slow-the-Spread Foundation, Inc. [grant number A97911 to P.C.T.]. Mention of a proprietary product does not constitute an endorsement or a recommendation for its use by USDA.

\section{References}

Baker TC, Cardé RT. 1979. Analysis of pheromone-mediated behaviors in male Grapholitha molesta, the oriental fruit moth (Lepidoptera: Tortricidae). Environ Entomol. 8:956-968.

Bengtsson M, Karg G, Kirsch PA, Lofqvist J, Sauer A, Witzgall P. 1994. Mating Disruption of Pea Moth CydiaNigricana F (Lepidoptera, Tortricidae) by a Repellent Blend of Sex-Pheromone and Attraction Inhibitors. J Chem Ecol. 20:871-887.

Beroza M, Hood CS, Trefrey D, Leonard DE, Knipling EF, Klassen W, Stevens LJ. 1974. Large field trial with microencapsulated sex pheromone to prevent mating of the gypsy moth. J Econ Entomol. 67:659-664.

Beroza M, Knipling E. 1972. Gypsy moth control with the sex attractant pheromone. Science. 177:19-27.

Biondi A, Mommaerts V, Smagghe G, Viñuela E, Zappalà L, Desneux N. 2012. The non-target impact of spinosyns on beneficial arthropods. Pest Manag Sci. 68:1523-1536.

Caprio MA, Suckling DM. 1995. Mating disruption reduces the risk of resistance development to transgenic apple orchards: simulations of the lightbrown apple moth: New Zealand. Rotorua: Plant Protection Society; p. 52-58.

Carde RT, Minks AK. 1995. Control of Moth Pests by mating disruption: successes and constraints. Annu Rev Entomol. 40:559-585.

Gesch D, Oimoen M, Greenlee S, Nelson C, Steuck M, Tyler D. 2002. The national elevation dataset. Photogramm Eng Remote Sensing. 68:5-32.

Granett J, Doane CC. 1975. Reduction of gypsy moth male mating potential in dense populations by mistblower sprays of microencapsulated disparlure. J Econ Entomol. 68:435-437.

Hide R, Suckling D. 1988. Decision analysis of insecticide resistance in light-brown apple moth. New Zeal J Exp Agric. 16:219-224.

Jenkins J, Doane C, Schuster D, Jimenez M. 1990. Development and commercial application of sex pheromone for control of the tomato pinworm. In: Silverstein RM, Ridgway RL, Inscoe MN, editors. Behavior-modifying chemicals for pest management: applications of pheromones and other attractants. New York: Marcel Dekker; p. 269-280.

Knipling EF. 1979. The basic principles of insect population suppression and management. Washington, D.C.: Agriculture Handbook. USDA.

Liebhold AM, Gottschalk KW, Muzika R-M, Montgomery ME, Young R, O'Day K, Kelley B. 1995. Suitability of North American tree species to the gypsy moth: a summary of field and laboratory tests. Radnor, PA: U.S. Dept. 
of Agriculture, Forest Service, Northeastern Forest Experiment Station.

Liebhold AM, Halverson JA, Elmes GA. 1992. Gypsy Moth Invasion in North America: a quantitative analysis. J Biogeogr. 19:513-520.

Louis F, Schirra K-J. 2001. Mating disruption of Lobesia botrana (Lepidoptera: Tortricidae) in vineyards with very high population densities. IOBC/WPRS Bull. 24: 75-80.

Miller JR, Gut LJ, de Lame FM, Stelinski LL. 2006a. Differentiation of competitive vs. non-competitive mechanisms mediating disruption of moth sexual communication by point sources of sex pheromone (Part 2): case studies. J Chem Ecol. 32:2115-2143.

Miller JR, Gut LJ, de Lame FM, Stelinski LL. 2006b. Differentiation of competitive vs. non-competitive mechanisms mediating disruption of moth sexual communication by point sources of sex pheromone (Part I): Theoryl. J Chem Ecol. 32:2089-2114.

Miller JR, Gut LJ. 2015. Mating disruption for the 21st century: matching technology with mechanism. Environ Entomol. 44:427-453.

Mori BA, Evenden ML. 2013. When mating disruption does not disrupt mating: fitness consequences of delayed mating in moths. Entomologia Experimentalis et Applicata. 146:50-65.

Morin RS. 2005. Mapping host-species abundance of three major exotic forest pests. Newtown Square (PA): U.S. Dept. of Agriculture, Forest Service, Northeastern Research Station.

Onstad DW. 2014. Insect resistance management: biology, economics, and prediction. Boston: Elsevier.

Onufrieva K, Onufriev A. 2018. PLoS ONE., Linear relationship between peak and season-long abundances in insects, 13(2), e0193110.

Pimentel D. 1995. Amounts of pesticides reaching target pests: environmental impacts and ethics. J Agric Environ Ethics. 8:17-29.

Plimmer JR, Leonhardt BA, Webb RE, Schwalbe CP. 1982. Management of the Gypsy-Moth with its sex attractant pheromone. ACS Symposium Series. 190:231-242.

R Development Core Team. 2016. R: a language and environment for statistical computing. Vienna: R Foundation for Statistical Computing.

Rice RE, Kirsch P. 1990. Mating disruption of oriental fruit moth in the United States. Behavior-modifying chemicals for insect management. New York: Marcel Dekker; p. 193-211.

Richerson JV, Brown EA, Cameron EA. 1976. Pre-Mating Sexual-Activity of Gypsy Moth Males in Small Plot FieldTests (Lymantria (=Porthetria) Dispar (L) Lymantriidae). Can Entomol. 108:439-448.

SAS Institute Inc. 2008. SAS/STAT ${ }^{\oplus} 9.2$ User's Guide. Cary, NC: SAS Institute Inc.

Schwalbe CP, Mastro VC. 1988. Gypsy-Moth (Lepidoptera, Lymantriidae) Mating Disruption - Dosage Effects. J Chem Ecol. 14:581-588.

Sharov, A A, Liebhold A M, Roberts E A. 1997. Methods for monitoring the spread of gypsy moth (Lepidotperta: Lymantriidae) populations in the Appalachian Mountains. J Econ Entomol. 90:1259-1266.

Sharov AA, Leonard D, Liebhold AM, Clemens NS. 2002. Evaluation of preventive treatments in low-density gypsy moth populations using pheromone traps. J Econ Entomol. 95:1205-1215.

Sharov AA, Liebhold AM, Ravlin FW. 1995. Prediction of gypsy moth (Lepidoptera: Lymantriidae) mating success from pheromone trap counts. Environ Entomol. 24: 1239-1244.

Sharov AA, Liebhold AM. 1998. Model of slowing the spread of gypsy moth (Lepidoptera: Lymantriidae) with a barrier zone. Ecol Appl. 8:1170-1179.

Stark RS, Cameron EA, Richerson JV. 1974. Determination of mating and fertility of female gypsy moths. J Econ Entomol. 67:296-297.

Stelinski LL, Gut LJ, Miller JR. 2013. An attempt to increase efficacy of moth mating Disruption by Co-releasing pheromones with kairomones and to understand possible underlying mechanisms of this technique. Environ Entomol. 42:158-166.

Suckling D, Shaw P, Khoo J, Cruickshank V. 1990. Resistance management of lightbrown apple moth, Epiphyas postvittana (Lepidoptera: Tortricidae) by mating disruption. NZ J Crop Hortic Sci. 18:89-98.

Suckling DM, Tobin PC, McCullough DG, Herms DA. 2012. Combining tactics to exploit Allee effects for eradication of alien insect populations. J Econ Entomol. 105:1-13.

Tcheslavskaia K, Brewster CC, Sharov AA. 2002. Mating success of gypsy moth (Lepidoptera: Lymantriidae) females in Southern Wisconsin. Great Lakes Entomol. 35(1):1-7. English.

Thorpe K, Reardon R, Tcheslavskaia K, Leonard D, Mastro V. 2006. A review of the use of mating disruption to manage gypsy moth, Lymantria dispar (L.). FHTET-2006-13. Morgantown, WV: U.S. Department of Agriculture, Forest Service, Forest Health Technology Enterprise Team.

Thorpe KW, Hickman AD, Tcheslavskaia KS, Leonard DS, Roberts EA. 2007. Comparison of methods for deploying female gypsy moths to evaluate mating disruption treatments. Agric For Entomol. 9:31-37.

Thorpe KW, Tcheslavskaia KS, Tobin PC, Blackbum LM, Leonard DS, Roberts EA. 2007. Persistent effects of aerial applications of disparlure on gypsy moth: trap catch and mating success. Entomologia Experimentalis et Applicata. 125:223-229.

Tobin, PC, Blackburn LM, Gray RH, Lettau CT, Liebhold AM, Raffa KF. 2013. Using delimiting surveys to characterize the spatiotemporal dynamics facilitates the management of an invasive non-native insect. Popul Ecol. 55:545-555.

Tobin P, Sharov A, Thorpe K. 2007. In: Tobin P, Blackbum LM, editors. Slow the spread: a national program to manage the gypsy moth. Newtown Square (PA): USDA FS Northern Research Station; p. 61-75, Chapter 5, The decision algorithm: project evaluation.

Tobin PC, Bai BB, Eggen DA, Leonard DS. 2012. The ecology, geopolitics, and economics of managing Lymantria dispar in the United States. Int J Pest Manage. 58:195210.

Tobin PC, Bolyard JL, Onufrieva KS, Hickman AD. 2014. The effect of male and female age on Lymantria dispar (Lepidoptera: Lymantriidae) fecundity. J Econ Entomol. 107:1076-1083.

Tobin PC, Klein KT, Leonard DS. 2009. Gypsy moth (Lepidoptera: Lymantriidae) flight behavior and phenology based on field-deployed automated pheromone-baited traps. Environ Entomol. 38(6):1555-1562. English.

Tobin PC, Liebhold AM, Roberts EA. 2007. Comparison of methods for estimating the spread of a non-indigenous species. J Biogeogr. 34:305-312.

Tobin PC, Onufrieva KS, Thorpe KW. 2013. The relationship between male moth density and female mating success in invading populations of Lymantria dispar. Entomologia Experimentalis et Applicata. 146:103-111. 
Tobin PC, Sharov AA, Liebhold AA, Leonard DS. 2004. Management of the gypsy moth through a Decision Algorithm under the STS Project. Am Entomol (Lanham, Md). 50(4):200-209.

Tobin PC, Whitmire SL, Johnson DM, Bjornstad ON, Liebhold AM. 2007. Invasion speed is affected by geographical variation in the strength of Allee effects. Ecol Lett. 10:36-43.

Walter JA, Meixler MS, Mueller T, Fagan WF, Tobin PC, Haynes KJ. 2015. How topography induces reproductive asynchrony and alters gypsy moth invasion dynamics. J Anim Ecol. 84:188-198.

Walton VM, Daane KM, Bentley WJ, Millar JG, Larsen TE, Malakar-Kuenen R. 2006. Pheromone-based mating disruption of Planococcus ficus (Hemiptera: Pseudococcidae) in California vineyards. J Econ Entomol. 99:12801290.

Witzgall P, Backman AC, Svensson M, Koch U, Rama F, ElSayed A, Brauchli J, Arn H, Bengtsson M, Lofqvist J. 1999. Behavioral observations of codling moth, Cydia pomonella, in orchards permeated with synthetic pheromone. Biocontrol. 44:211-237.

Witzgall P, Kirsch P, Cork A. 2010. Sex pheromones and their impact on pest management. J Chem Ecol. 36:80100.

Witzgall P, Stelinski L, Gut L, Thomson D. 2008. Codling moth management and chemical ecology. Annu Rev Entomol. 53:503-522. 